\title{
Beyond Adoption: Barriers to an Online Assignment Submission System Continued Use
}

\author{
Nitza Geri \\ The Open University of \\ Israel \\ Raanana, Israel
}

nitzage@openu.ac.il

\author{
Orit Naor-Elaiza \\ Bar-Ilan University \\ Ramat-Gan, Israel, and \\ The Open University of Israel \\ Raanana, Israel \\ oritna@openu.ac.il
}

\begin{abstract}
Understanding the factors that affect continued use or discontinuance of an information system beyond initial adoption is one of the most challenging issues in information systems research. This paper combines information economics, the technology acceptance model (TAM), and diffusion of innovation theory, and analyzes barriers with respect to the continued use of information systems. The suggested model examines data collected from 284 former users enrolled in a blended distance learning university, who apparently abandoned an online assignment submission system. The findings indicate that behavioral intention to use the system was mainly influenced by its perceived ease of use, perceived usefulness, its real value, and general attitude towards new technologies. Social and institutional influence was quite low, but the major barrier to continuance was incompatibility with the assignment preparation process performed by the students, as well as the assignment checking process performed by the tutors, which discouraged continued use.
\end{abstract}

Keywords: information systems continued use, continuance, technology acceptance model (TAM), diffusion of innovation, human computer interaction, value of information systems, distance learning.

\section{Introduction}

The continued use, or continuance (Bhattacherjee, 2001), of information systems is a well recognized challenge (Delone \& Mclean, 1992, 2003), especially regarding complex information systems, such as knowledge management systems (Bush \& Tiwana, 2005). However, when the system is relatively simple, like the online assignment submission system analyzed in this paper, it was not supposed to be so. Although technology acceptance and continuance has been exten-

Material published as part of this publication, either on-line or in print, is copyrighted by the Informing Science Institute. Permission to make digital or paper copy of part or all of these works for personal or classroom use is granted without fee provided that the copies are not made or distributed for profit or commercial advantage AND that copies 1) bear this notice in full and 2) give the full citation on the first page. It is permissible to abstract these works so long as credit is given. To copy in all other cases or to republish or to post on a server or to redistribute to lists requires specific permission and payment of a fee. Contact Publisher@InformingScience.org to request redistribution permission. sively researched (Davis, 1989; Moore \& Benbasat, 1991; Rogers, 1962, 2003), understanding why people adopt or reject an information system is still one of the most challenging issues in information systems research (Agarwal \& Prasad, 1997; Jeyaraj, Rottman, \& Lacity, 2006; Kim \& Malhotra, 2005; Venkatesh, Morris, Davis, \& Davis, 2003). 
This paper examines an online assignment submission system (which seems very similar to an email system) implemented in a blended distance learning university. Such a system expedites the process of task handling and provides students with fast feedback on their work. This apparently simple feature has been recognized as one of the most valued online activities by graduate Management Information Systems (MIS) students who were enrolled in online courses in a major university located in southeastern United States (Levy, 2006). Students of mathematics at the Open University of Hong Kong suggested that an online submission system, which was not available at that time, would improve the online learning environment (Chan \& Waugh, 2007). Therefore, an online assignment submission system should be expected to be valuable primarily in a distance or blended learning environment. However, after seven years of implementation, the online system examined in this paper handled less than $20 \%$ of the assignments. This paper is part of a comprehensive research project that investigates the assignment system's slow adoption rate. The study focuses on the students who used the system in the past, hereafter referred to as former users, but apparently abandoned it.

The next section presents the suggested research model and hypotheses regarding the behavioral intentions of users or former users of an information system. The sections that follow describe the methodology used to examine empirically the model, and the results. The paper ends with discussion of the theoretical and practical implications of the findings, and conclusions.

\section{The Research Model and Hypotheses}

Figure 1 presents the proposed research model, which combines information economics (Ahituv, 1980, 1989; Raban, 2007) with the Technology Acceptance Model (TAM) (Davis, 1989; Davis, Bagozzi, \& Warshaw, 1989; Venkatesh et al., 2003), as well as Rogers' $(1962,2003)$ diffusion of innovation theory, and draws on prior research on information technology adoption (Jeyaraj et al., 2006) and continued use (Bhattacherjee, 2001; Bhattacherjee \& Premkumar, 2004; Gefen, 2003;

Karahanna, Straub, \& Chervany, 1999; Kim \& Malhotra, 2005).

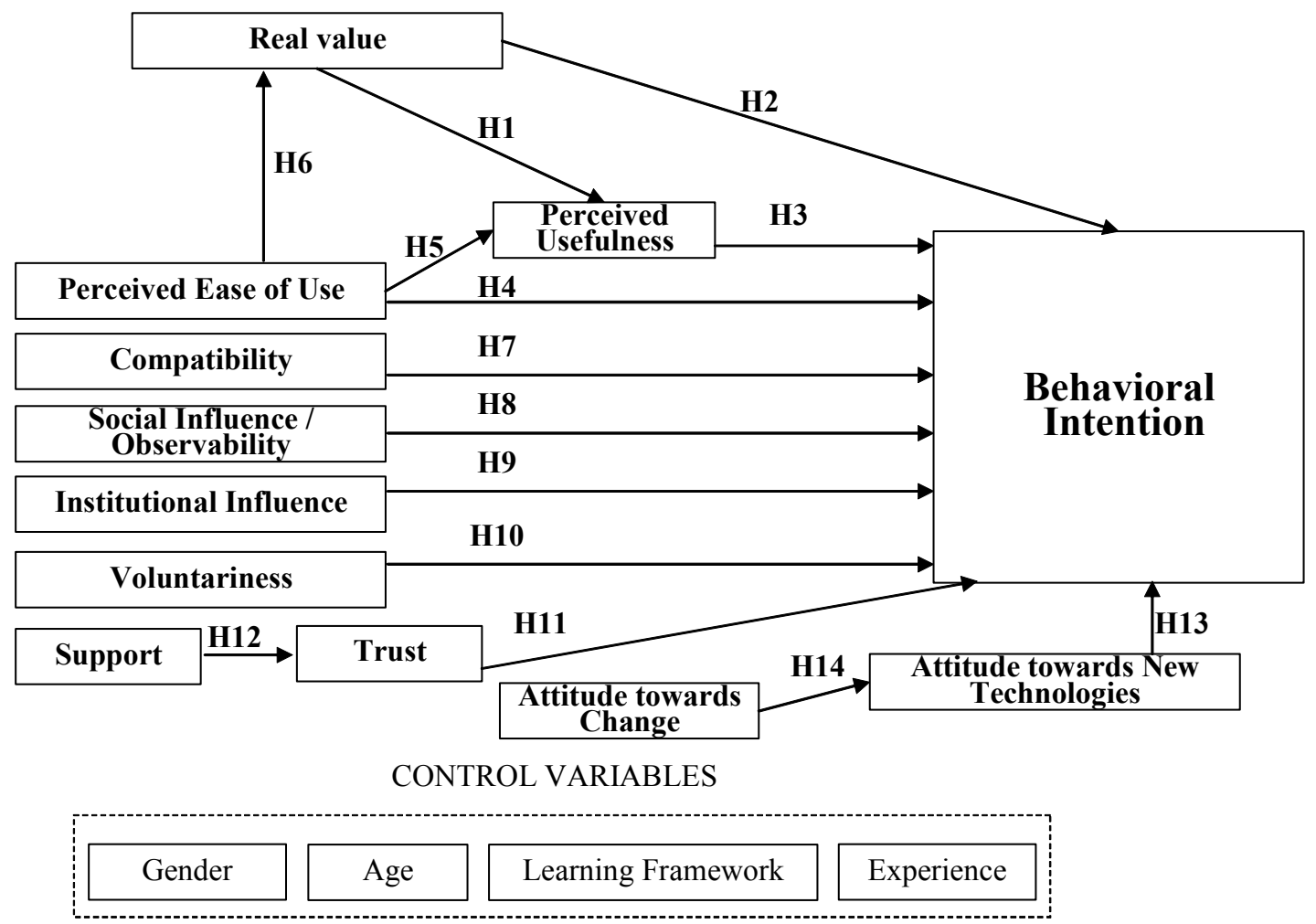

Figure 1: The Suggested Research Model 
Information economics distinguishes between the real value of an information system and its perceived value (Ahituv, 1989). Real value relates to tangible benefits of an information system, such as reduced transaction costs or faster service. Perceived value concerns the perceptions of the users or the potential users of an information system and is similar to the term Perceived Usefulness (PU), which is one of the principal constructs of the Technology Acceptance Model (Davis, 1989; Davis et al., 1989). Hereafter, perceived usefulness will encompass the term perceived value. According to TAM, perceived usefulness is the degree to which an individual believes that using a particular system will enhance his or her performance (Davis, 1989).

The real value of information is not necessarily positively correlated with perceived usefulness. Consider for instance a new website of a bank that enables customers to view their account and perform transactions online. The website saves the customers time and money and provides them with useful information. Hence, the real value of the information system should be high. However, the response time is not satisfactory and, therefore, the impatient customers prefer to call the clerk instead of using the system. Although the website provides the customers with flexibility (e.g., they may carry out transactions in the middle of the night) and the transaction is less prone to errors due to conversational misunderstandings, when the customers are asked about the PU of the system, their evaluations will be low. Nevertheless, it is expected that in most cases, real value will positively influence PU.

H1: Real value positively affects perceived usefulness.

Moreover, it is expected that people who attribute higher real value to a certain system will be more inclined to use that system.

H2: Real value positively affects behavioral intention.

The second main construct of TAM is Perceived Ease of Use (PEOU), defined as the degree to which an individual believes that using a particular system will be free of physical or mental effort (Davis, 1989). The following hypotheses are based on TAM and were widely supported in prior research (Venkatesh et al., 2003):

H3: Perceived usefulness positively influences behavioral intention.

H4: Perceived ease of use positively influences behavioral intention.

H5: Perceived ease of use positively influences perceived usefulness.

It is expected, as well, that higher PEOU will positively influence the real value of an information system.

H6: Perceived ease of use positively affects real value.

The next hypotheses are based on diffusion of innovation theory (Rogers, 2003) and information systems adoption research (Jeyaraj et al., 2006; Venkatesh et al., 2003). One of the main factors that has been found to influence behavioral intention is compatibility, which is the extent to which adopting the innovation is compatible with what the potential users do (Rogers, 2003). However, prior research examined different aspects of compatibility with mixed results (Karahanna, Agarwal \& Angst, 2006). In this research, compatibility refers to Rogers' (2003) definition and examines the influence of the system's fit with tasks on behavioral intention.

H7: Compatibility positively influences behavioral intention.

Observability is the degree to which the results of an innovation are visible to others. In this study, it is combined with social influence, which refers to the influence of others, such as friends and classmates, on the individual (Ajzen \& Fishbein, 1980). Venkatesh et al. (2003) have found that social influence affected behavioral intention, and the effect was stronger for women and for older workers when the system use was mandatory and the users had limited experience. How- 
ever, the construct developed by Venkatesh et al. (2003) included both peer influence and management influence. In this research, these two aspects were examined separately, while the construct social influence encompasses peer influence and observability, the construct institutional influence refers to management influence.

H8: Social influence and observability positively affect behavioral intention.

In this study, institutional influence refers to the influence of relevant organizations or institutions on the individual (Moore \& Benbasat, 1991). In the context of the assignments system analyzed here, it refers to the influence of the university authorities, as well as the course coordinators and tutors, on the students.

H9: Institutional influence has a positive effect on behavioral intention.

Voluntariness is closely related to institutional influence. It is not a simple matter of whether the use of the system is obligatory or not; voluntariness is the degree to which the potential or actual user perceives the system use as voluntary (Moore \& Benbasat, 1991). Since the use of the assignments system, analyzed in this study is not mandatory for the students, those that feel that they are expected to use the system will be more inclined to use it.

H10: Voluntariness positively influences behavioral intention.

Trust in the context of this research is defined as the extent to which the innovation adopter perceives the innovation provider to be trustworthy (Barnes \& Huff, 2003). Trust has been found to influence buyer behavioral intention in commercial websites (Gefen, Karahanna, \& Straub, 2003; Pavlou \& Gefen, 2004). While a public organization or an academic institute is inherently trustworthy regarding the aspect of not deceiving a user intentionally, sometimes it may be very hard to correct user mistakes. Hence, trust may also represent the user belief that there are adequate procedures to handle mistakes.

H11: Trust positively influences behavioral intention.

Support refers to user perceptions on the available help and technical support (Travica, 2007), and the availability of adequate support should enhance user trust. However, the importance of support depends on the complexity of the system, and it may differ with regard to novel users and experienced users. Since this study deals with former users, it examined the support aspect, although apparently the assignments system is supposed to be relatively simple.

H12: Support has a positive influence on trust.

Early adopters of new technologies are more likely to adopt new information systems (Rogers, 2003). Although attitude toward the specific adopted information system has been considered in prior research (Venkatesh et al., 2003), general attitude towards new technologies has not been examined in the context of technology acceptance and continued use of information systems.

H13: Positive attitude towards new technologies increases behavioral intention.

Those who are more adaptive to changes will tend to have a more positive attitude towards adopting new technologies (Rogers, 2003). This assumption also has not been empirically tested in information systems contexts.

H14: Attitude towards change positively affects attitude towards new technologies.

The model was controlled for:

- Gender, which is a factor that influences information and communication technology adoption (Gefen, Geri, \& Paravastu, 2007). 
- Age, which was found to influence performance in various digital environments (e.g., Eshet-Alkalai \& Geri, 2007).

- Learning Framework - i.e., whether the student is independent or enrolled in a learning center. Students who study in a learning center usually have more face-to-face contact with the tutors and their classmates because they tend to attend class sessions.

- Experience - proficiency in relevant applications such as e-mail and word processor. This control factor follows Koohang (2004), who found that users' prior experience with the Internet had significantly higher positive perceptions toward e-learning courseware usability.

\section{Methodology}

The research model has been tested at the Open University of Israel, which is a distance learning institute with over 40,000 students. The Open University offers its students the choice of a full distance learning model or a blended learning model. Students who choose the blended model combine a few face-to-face meetings with online support through course websites to supplement traditional means of distance education, such as books and study guides. The research reported in this paper is part of a comprehensive on-going research that analyses all the parties concerned with the assignments system of the Open University: the students, the course coordinators, the tutors, and the university management.

The assignments system is a web-based system that enables the students to submit their assignment online, trace its status, and receive feedback from the tutor along with the assignment grade. The system can handle all the prevalent sorts of files, and the process of submitting an assignment and grading it by the tutor can be paperless. However, a few tutors prefer to download the assignments, print them, read the printed version, and then add their comments to the digital version and return the assignments to the students via the system. The students' use of the system is mainly voluntary, and it offers them an alternative to sending their assignment via regular mail or handing it in person if they choose to attend a class meeting. Still, the option to use the assignments system has not been available in all the courses and it depended on the course coordinator's willingness to use the system. As of 2007, the university management encourages the implementation of the system in all courses. As a first step, the course coordinators of courses with three study groups or more had to appoint at least one tutor who would check all the assignments that were submitted via the assignments system and to offer all the students enrolled in that course to use the system, even if they were instructed in class by another tutor who chose not to use the system. Nonetheless, the students still have the choice whether to use the system or not. This choice is considered within the general flexibility the Open University offers its students.

The assignments system was inaugurated in February 1999 (the spring semester of 1999) and 123 assignments were submitted through it. Seven years later, during the spring semester of 2006, 34,500 assignments were submitted via the system, which is less than $20 \%$ of all the assignments that were submitted in that semester. This paper focuses on former users, who are defined as students who have submitted assignments through the system in previous semesters but did not use it in the spring semester of 2007 and, apparently, abandoned the system.

A pilot of the questionnaire was conducted in July 2007. An e-mail was sent to randomly chosen 300 non-users, 300 former users and 300 users, asking them to answer an anonymous web survey concerning the assignments system. 23 non-users (7.7\% response rate), 38 former users $(12.7 \%$ response rate), and 73 users ( $24.3 \%$ response rate) answered the pilot survey. Following the analysis of the 134 responses, the questionnaire was slightly refined. In August 2007, the final questionnaire was sent by e-mail to 2,633 randomly chosen students out of the 4,000 former user population with known e-mail addresses. About 150 mails were returned with wrong address 
messages or other delivery failure announcements. 189 respondents answered the questionnaire within a week with an additional 95 students after a reminder. This resulted in a total of 284 responses, which is an overall $11.4 \%$ effective response rate (the unusable partial responses were excluded from the analysis). Non-response bias was assessed by comparing the early respondents and the late respondents (those who answered after the reminding e-mail) based on Armstrong and Overton (1977). Analysis of variance (ANOVA) test showed that there were no significant differences between these two groups in 29 out of the 31 items, however early respondents were a bit more supportive of the system (item BI2, average scores: 5.9 and 5.4) and they were slightly more adaptive to changes (item ATC1, average scores: 5.5 and 5.0).

\section{Results}

Demographic characteristics of the 284 students who answered the former users survey are presented in Table 1. There were no age or learning framework differences in the model. Gender affected just the social influence/observability construct, and this result supports the findings of Venkatesh and Morris (2000), who showed that women are more affected by social norms in their adoption of information and communication technologies.

\begin{tabular}{|c|c|c|c|c|c|}
\hline \multicolumn{6}{|c|}{ Table 1. Demographic characteristics of survey participants } \\
\hline \multirow{2}{*}{ Gender } & Men & Women & & & \\
\hline & $45.4 \%$ & $54.6 \%$ & & & \\
\hline \multirow{2}{*}{$\begin{array}{l}\text { Learning } \\
\text { framework }\end{array}$} & Institutional & Independent & & & \\
\hline & $44.0 \%$ & $56.0 \%$ & & & \\
\hline \multirow{2}{*}{ Age } & 20-29 & 30-39 & 40-49 & 50-59 & Over 60 \\
\hline & $39.8 \%$ & $44.0 \%$ & $12.0 \%$ & $3.9 \%$ & $0.3 \%$ \\
\hline
\end{tabular}

Partial Least Squares (PLS) (Chin, 1998; Chin, Marcolin \& Newsted, 2003) was used to analyze the data with SmartPLS 2.0 (beta) software (Ringle, Wende \& Will, 2005). PLS is a structured equation modeling method that analyzes how the items load on their constructs simultaneously with estimating all the paths in the model and is extensively used in MIS research (Gefen \& Straub, 2005). PLS estimates all paths, loadings, and Average Variance Extracted (AVE) of principal constructs and construct reliability. Convergent and discriminant validity are shown when each item loads much higher on its assigned factor than on any other factor and when the square root of the AVE of each construct is much larger than the correlation of that construct with all other constructs. The instrument items are presented in Appendix A. Appendix B details the confirmatory factor analysis in PLS. Appendix C lists the mean, standard deviation, and PLS reliability of the constructs, together with the correlation among the constructs and their square root of the AVE. All these measures are above the limit values suggested in the literature (Gefen, Straub $\&$ Boudreau, 2000). Hence, the constructs have adequate convergent and discriminant validity.

Figure 2 shows the standardized PLS path coefficients model. The coefficients are shown next to the arrows, and all are significant at least at the .05 level. The R-squared values are shown inside the box of the relevant constructs. All other paths between constructs were insignificant. Behavioral intention to use the assignment system was directly influenced by perceived ease of use, perceived usefulness, real value, and attitude towards new technologies. As expected by the TAM literature, PEOU affected PU, as well as real value, whereas real value positively affected PEOU. Hence, hypotheses H1, H2, H3, H4, H5, and H6, which are based on TAM and information economics, were all supported, as well as H13. H14, which suggested that attitude towards 


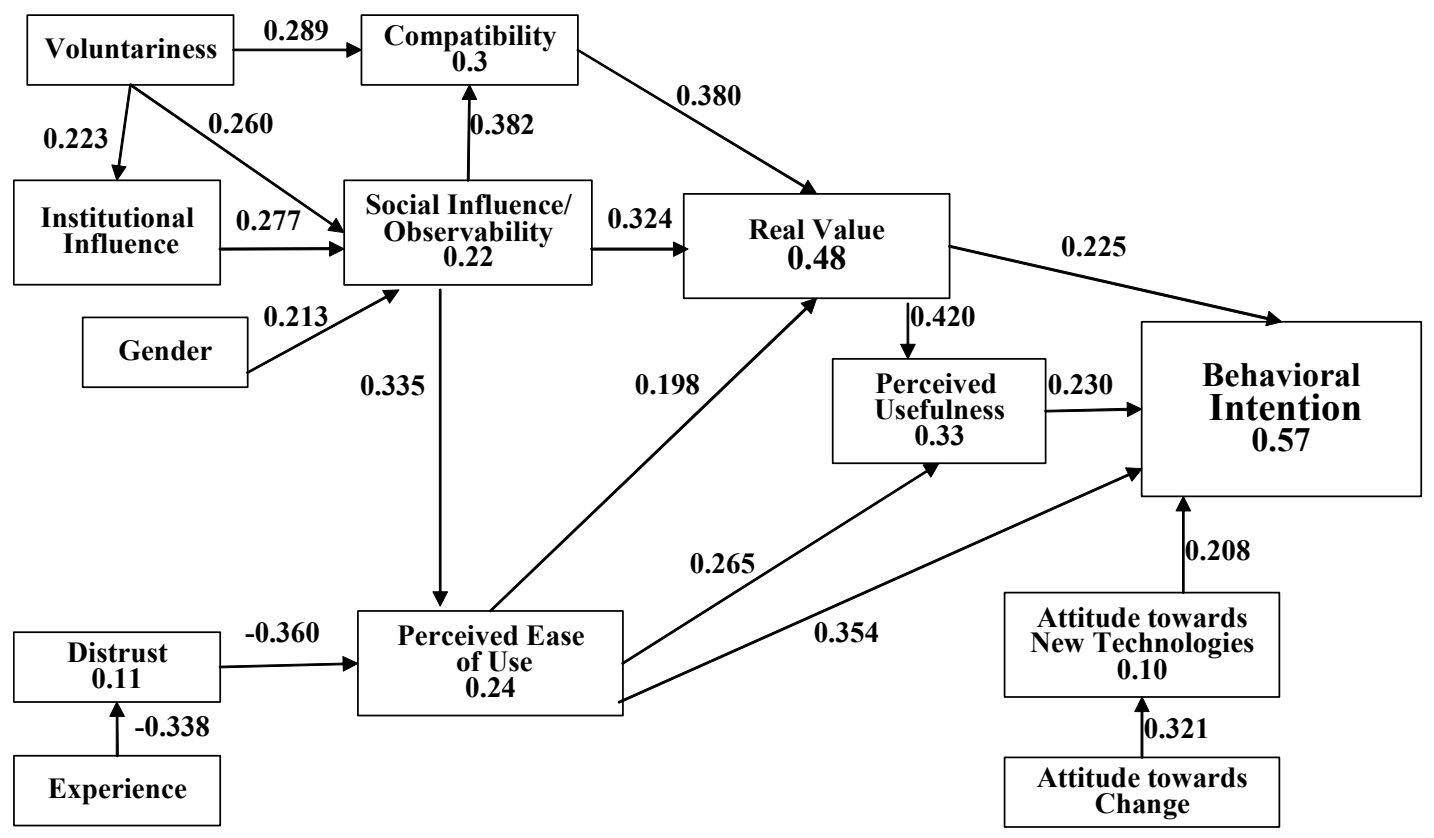

Figure 2: PLS Results for the Proposed Research Model

change influences attitude towards new technologies was also supported. However, compatibility, social influence/observability, institutional influence, voluntariness, and trust did not have a direct significant effect on behavioral intention, as predicted by H7, H8, H9, H10 and H11. Nevertheless, all these constructs had an indirect effect on behavioral intention. Compatibility and social influence/observability enhanced real value. Furthermore, social influence/observability strongly affected compatibility. Institutional influence affected the social influence/observability construct, so it also had some indirect effect on behavioral intention. Voluntariness affected compatibility, social influence/observability, and institutional influence. Distrust negatively influenced PEOU, and the participants' experience in relevant information technologies use reduced their level of distrust. Conversely, the participants' perceptions of the available support did not affect their trust; hence, H12 was rejected.

Although the participants were former users who did not use the assignment system and apparently abandoned it, they were inclined to use it in the future, and the average of the behavioral intention construct was 5.54 (on a scale of 1 to 7). There were also two open questions; the first one was, "If you stopped using the systems, please explain why", and 77 participants (27\%) answered it. The second question called for remarks, general feedback and so forth, and there were 99 answers (35\%). Some of the answers included more than one reason, and altogether there were 194 answers. 37 of these were general remarks (e.g. "good luck in your research"), and the 157 remaining answers are categorized in Table 2. 
Table 2. Reasons for not using the assignments system

\begin{tabular}{|l|c|c|}
\hline $\begin{array}{l}\text { I would like to use the system but: It is not offered in the } \\
\text { courses I take this semester / The course coordinator or my spe- } \\
\text { cific tutor does not allow using the system. }\end{array}$ & 65 & $41.4 \%$ \\
\hline $\begin{array}{l}\text { In principle, I would like to use the assignments system but: It is } \\
\text { not convenient to draw graphs or type formulas and equations } \\
\text { (and it is not allowed to scan the assignment in these specific } \\
\text { courses) / I do not have a scanner at home. }\end{array}$ & 43 & $27.4 \%$ \\
\hline $\begin{array}{l}\text { The system denotes late submission in red, even if the tutor gave } \\
\text { an extension, or even if I supposedly submitted the assignment } \\
\text { only one minute late (after midnight). }\end{array}$ & 14 & $8.9 \%$ \\
\hline $\begin{array}{l}\text { It is easier for me to submit at class or via regular mail / It is not } \\
\text { easy for me to use the system }\end{array}$ & 13 & $8.3 \%$ \\
\hline Because I do not have to use the system. & 11 & $7.0 \%$ \\
\hline I do not trust the system / The system is not good. & 7 & $4.5 \%$ \\
\hline $\begin{array}{l}\text { My decision is affected by the instructor who checks the as- } \\
\text { signments. I prefer that my tutor will check the assignments and } \\
\text { not someone else who may have other criteria. }\end{array}$ & 4 & $2.5 \%$ \\
\hline Total & 157 & $100 \%$ \\
\hline
\end{tabular}

\section{Discussion}

\section{Discussion of the Findings and Theoretical Implications}

This research examined barriers to continued use of a simple information system, which in essence is very similar to ubiquitous e-mail applications. The participants of this study were supposedly former users of the assignments system and it would be expected that their behavioral intention to continue using it would be low. On the contrary, the average value of the behavioral intention construct was quite high (5.54, SD 1.49), and since the R-squared value of the construct was 0.57 , the results suggest an explanation to the participants' tendency to use the system in the future. The factors, which according to information economics (Ahituv, 1989) and TAM (Davis, 1989) influence behavioral intentions, were all significant. The TAM constructs' values were relatively high: PEOU was 5.7 (SD 1.25), and PU, which also represents perceived value in information economics terms (Ahituv, 1989), was 5.36 (SD 1.24). However, the average real value was lower (4.68, SD 1.38). It may be interpreted that the former users perceive the assignments system as potentially valuable and easy to use, but their actual benefits of using it are low because actually they currently do not use it.

The participants' self-reported attitude towards change was relatively high (5.98, SD 1.07) and it significantly influenced their attitude towards new technologies (4.99, SD 1.54), which in turn positively affected behavioral intention. These connections were not examined in prior MIS research. It should be noted that the term "attitude toward using technology," in the UTAUT (Unified Theory of Acceptance and Use of Technology) model suggested by Venkatesh et al. (2003), refers to the user attitude toward the specific information system (e.g., "I like working with the system", "The system makes work more interesting"). Whereas the constructs examined in this research relate to general attitudes towards change and new technologies (e.g., "It is easy for me 
to cope with changes", "It is important for me to use advanced technologies"). Hence, the inclusion of attitude towards change and attitude towards new technologies in the factors that affect behavioral intention to use an information system, together with empirical evidence that supports these hypotheses, are important contributions of this research.

Unlike findings of prior research (Gefen et al., 2003), trust did not directly affect behavioral intention. This may be explained by the different environments. While Gefen et al. (2003) related to a commercial website, where buyer trust is not self evident, the service provider in this study is a university, and a priory, it should be trustworthy. However, this study addressed these differences and defined trust as the user belief that there are adequate procedures to handle mistakes. The construct measured distrust, i.e., inability to correct mistakes, and the relatively low value of the construct (2.56, SD 1.46) indicates that the participants trust the system. Yet, distrust had a negative significant influence on PEOU, and it may be interpreted that potential users that were afraid they would not be able to correct their mistakes and perceived the system as less easy to use. The participants had relevant experience (6.30, SD 0.91) and it reduced their distrust in the system. Also, adequate support, which is crucial in complex or nontrivial system environments (Travica, 2007), did not have a significant influence on distrust, and this can be explained by the simplicity of the assignments system.

Social influence/observability, institutional influence, and voluntariness did not have a direct influence on behavioral intention, and overall, their average values were quite low, from 3.63 to 4.48 (see Appendix C). Therefore, the findings suggest that low levels of social and institutional influence do not have a direct effect on behavioral intention of former users. Nonetheless, such influence may still affect the real value of the system, its PEOU, and even its compatibility, as shown by the results. However, it cannot be concluded from the findings that high levels of social influence/observability and institutional influence, combined with creating a feeling of obligation to use the system do not influence decisions of former users regarding continued use of the system, because such conditions were not evident in this particular instance. These issues are discussed further in the practical implications of this research.

Compatibility has been found in prior research as one of the main determinants of system usage (Karahanna et al., 2006). However, compatibility did not have a significant direct influence on behavioral intention in this study, but it strongly affected the real value of the system. The average score of the compatibility construct was quite low, 4.19 , with a relatively high $\mathrm{SD}, 1.43$. Hence, it may be interpreted that those students who perceived the assignments system as compatible with their needs, attribute relatively high real value to the system, and vice versa. The low level of compatibility was also evident in the students' comments (see Table 2); 43 of them stated that, in principle, they would like to use the assignments system but it is not convenient to draw graphs or type formulas and equations and so forth. There were other comments, which are related to compatibility aspects, such as the strict documentation of late submission. The lack of compatibility combined with the low level of social influence may explain why these students discontinued using the system, at least temporarily, despite its relatively high PU and PEOU and their declared attentions to use it in the future.

\section{Practical Implications}

The practical implications of this study relate mainly to the social influence/observability, institutional influence, voluntariness, and compatibility aspects, and tie them together. The findings suggest that the former users may not have been sufficiently encouraged to use the assignments system. Similar results were found in a study of students that have never used the assignments system (Naor-Elaiza \& Geri, 2008). Moreover, the former users' answers as to the reasons for not using the system reveal that 65 of them ( $23 \%$ of the participants, $41 \%$ of those who commented) would like to use the system but it was not offered in the courses they took and either the course 
coordinator or their specific tutor discouraged using it (see Table 2). This raises the question why the course coordinators and the tutors did not want the students to use the assignments system. The answer, which will be further analyzed in a planned future research, is that probably the assignments system is not compatible with the needs of those course coordinators and tutors. One explanation may be related to differences in critical reading of print and digital formats (EshetAlkalai \& Geri, 2007). The tutors are required to critically read many assignments, and they feel, or know from their own experience, that their performance is better when they read printed material. Spencer (2006) found that learners preferred printed materials for reasons of portability, dependability, flexibility, and ergonomics. The preference for a certain format is relevant for the tutors as well as the students.

Hence, although the assignments system is indeed easy to use as e-mail, if one considers only the assignments transfer from the student to the tutor and vice versa, the practical implications of the system use, on how students prepare assignments and on the way tutors check them, are major. Therefore, the slow adoption rate of the assignments system may be a consequence of insufficient support of the assignment preparation and the assignment checking processes.

\section{Limitations and Further Research}

The study concerned one system conducted at one university, therefore it should be replicated in other and more varied settings, including other e-learning and business systems, in order to generalize its findings. While the context may be different from systems that are used within an organization, e.g., ERP, the findings may be relevant to systems that are aimed at customers. For instance, many businesses provide their customers with alternative communication channels. The customer may use the website or call a service center, or send a fax/regular mail, or visit a service center. Most businesses would like to encourage their customers, or at least certain types of customers, to use the website as a primary communication channel. The findings of this study may be useful as a basis for further studies concerning continued use of such systems.

This paper is part of a comprehensive study of the assignments system, which investigates the reasons for its slow adoption rate. It focused on the former users that apparently abandoned the system. A previous paper (Naor-Elaiza \& Geri, 2008) dealt with those students that have never used the system. The next steps involve analyzing those students who use the system and comparing them to non-users and former users. Moreover, the reasons for some course coordinators and tutors to disallow the use of the assignments system are further studied in a study, which is still in progress. Some possible explanations were suggested in the Discussion Section of this paper.

\section{Conclusion}

The continued use of an information system is necessary for realizing its potential value (Agarwal \& Prasad, 1997; Delone \& Mclean, 1992, 2003). This study examined former users of a simple assignment submission system, who apparently abandoned it, in order to identify the barriers to its continuance. The research model was based on information economics (Ahituv, 1989), TAM (Davis, 1989), and diffusion of innovation theory (Rogers, 2003). Prior technology acceptance research focused mainly on adopters, or users, or a comparison of the different antecedents that affect their behavioral intentions (e.g., Karahanna et al., 1999), whereas this study analyzed former users, therefore it provided unique insights with regard to discontinuance.

The data analysis revealed that, actually, the behavioral intention was quite high and it was directly influenced by the real value of the system, its perceived usefulness and perceived ease of use, as well as general attitude towards new technologies, which was influenced by attitude towards change. The inclusion of the latter two constructs in the factors that affect behavioral inten- 
tion to use an information system and its empirical validation are noteworthy contributions of this research.

Social influence/observability, institutional influence, and voluntariness, as well as compatibility, did not directly influence behavioral intention, and their average values were low. Thus, the findings suggest that low levels of these constructs do not have a direct affect on behavioral intention of former users. However, these findings may not be applicable to system environments that are characterized by high levels of compatibility, social, and institutional influence.

The slow adoption rate of the relatively simple assignments system, which was analyzed in this study, may result from insufficient support of the more complex computerized assignment preparation and the assignment checking processes. Augmented levels of social and institutional influence may enhance initial adoption, but unless these incompatibility issues are not resolved, the users will try to avoid using the system.

\section{References}

Agarwal, R., \& Prasad, J. (1997). The role of innovation characteristics and perceived voluntariness in the acceptance of information technologies. Decision Sciences, 28(3), 557-582.

Ahituv, N. (1980). A systematic approach toward assessing the value of an information system. MIS Quarterly, 4(4), 61-75.

Ahituv, N. (1989). Assessing the value of information: Problems and approaches. Proceedings of the 10th Annual International Conference on Information Systems, Boston, MA (December 1989): 315-325.

Ajzen I., \& Fishbein, M. (1980). Understanding attitudes and predicting social behavior. Englewood Cliffs, NJ: Prentice Hall.

Armstrong, J. S., \& Overton, T. S. (1977). Estimating nonresponse bias in mail surveys. Journal of Marketing Research, 14(August), 396-402.

Barnes, S. J., \& Huff S. L. (2003). Rising sun: iMode and the wireless internet. Communications of the $A C M, 46(11), 78-84$.

Bhattacherjee, A. (2001). Understanding information systems continuance: An expectation-confirmation model. MIS Quarterly, 25(3), 351-370.

Bhattacherjee, A., \& Premkumar, G. (2004). Understanding changes in belief and attitude toward information technology usage: A theoretical model and longitudinal test. MIS Quarterly, 28(2), 229-254.

Bush, A., \& Tiwana, A. (2005). Designing sticky knowledge networks. Communications of the ACM, 48(5), 66-71.

Chan, M., \& Waugh, R. (2007). Factors affecting student participation in the online learning environment at the Open University of Hong Kong. The Journal of Distance Education / Revue de l'Éducation à Distance [Online] 21(3), 23-38. Retrieved February 27, 2008 from http://www.jofde.ca/index.php/jde/article/view/31

Chin, W. W. (1998). Issues and opinions on structural equation modeling. MIS Quarterly 22(1), 7-16.

Chin, W. W., Marcolin, B. L., \& Newsted, P. R. (2003). A partial least squares latent variable modeling approach for measuring interaction effects: Results from a Monte Carlo simulation study and an electronic mail adoption study. Information Systems Research, 14(2), 189-217.

Davis, F. D. (1989). Perceived usefulness, perceived ease of use, and user acceptance of information technology. MIS Quarterly, 13(3), 318-340.

Davis, F. D., Bagozzi, R. P., \& Warshaw, P. R. (1989). User acceptance of computer technology: A comparison of two theoretical models. Management Science, 35(8), 982-1004. 
Delone, W. H., \& Mclean, E. R. (1992). Information systems success: The quest for the dependent variable. Information Systems Research, 3(1), 60-95.

Delone, W. H., \& Mclean, E. R. (2003). The DeLone and McLean model of information systems success: A ten-year update. Journal of Management Information Systems, 19(4), 9-30.

Eshet-Alkalai, Y., \& Geri, N. (2007). Does the medium affect the message? The influence of text representation format on critical thinking. Human Systems Management, 26(4), 269-279.

Gefen, D. (2003). TAM or just plain habit: A look at experienced online shoppers. Journal of End User Computing, 15(3), 1-13.

Gefen, D., Geri, N., \& Paravastu, N. (2007). Vive la différence: The cross-culture differences within us. International Journal of e-Collaboration, 3(3), 1-16.

Gefen, D., Karahanna, \& Straub, D. W. (2003). Trust and TAM in online shopping: An integrated model. MIS Quarterly, 27(1), 51-90.

Gefen, D., \& Straub, D. W. (2005). A practical guide to factorial validity using PLS-Graph: Tutorial and annotated example. Communications of the AIS, 16(5), 91-109.

Gefen, D., Straub, D. W., \& Boudreau, M. C. (2000). Structural equation modeling and regression: Guidelines for research practice. Communications of the AIS, 4(7), 1-78. Retrieved February 27, 2008 from http://www.cis.gsu.edu/ dstraub/Papers/Resume/Gefenetal2000.pdf

Jeyaraj, A., Rottman, J. W., \& Lacity, M. C. (2006). A review of the predictors, linkages, and biases in IT innovation adoption research. Journal of Information Technology, 21(1), 1-23.

Karahanna, E., Agarwal, R., \& Angst, C. M. (2006). Reconceptualizing compatibility beliefs in technology acceptance research. MIS Quarterly 30(4), 781-804.

Karahanna, E., Straub, D. W. \& Chervany, N. L. (1999). Information technology adoption across time: A cross-sectional comparison of pre-adoption and post-adoption beliefs. MIS Quarterly 23(2), 183-213.

Kim, S. S., \& Malhotra, N. K. (2005). A Longitudinal model of continued IS use: An integrative view of four mechanisms underlying post-adoption phenomena. Management Science, 51(5), 741-755.

Koohang, A. (2004). Expanding the concept of usability. Informing Science Journal, 7, 129-141. Retrieved from http://inform.nu/Articles/Vol7/v7p129-141-002.pdf

Levy, Y. (2006). The top 10 most valuable online learning activities for graduate MIS students. International Journal of Information and Communication Technology Education, 2(3), 27-44.

Moore, G. C., \& Benbasat, I. (1991). Development of an instrument to measure the perceptions of adopting an information technology innovation. Information Systems Research, 2(3), 192-222.

Naor-Elaiza, O., \& Geri, N. (2008). Easy as e-Mail? Probing the Slow Adoption of an Online Assignment Submission System. In Y. Eshet-Alkalai, A. Caspi, \& N. Geri (Eds.), Learning in the Technological Era: Proceedings of the Chais Conference on Instructional Technologies research (pp. 94-101). Raanana, Israel: The Open University of Israel. Retrieved February 27, 2008 from http://telem-pub.openu.ac.il/users/chais/2008/morning/1_2.pdf

Pavlou, P.A., \& Gefen, D. (2004). Building effective online marketplaces with institution-based trust. Information Systems Research, 15(1), 37-59.

Raban, D. R, (2007). User-centered evaluation of information: A research challenge. Internet Research, 17(3), 306-322.

Ringle, C. M., Wende, S., \& Will, A. (2005). SmartPLS 2.0 (beta). Retrieved from http://www.smartpls.de

Rogers, E. M. (1962). Diffusion of innovation. New-York: The Free Press.

Rogers, E. M. (2003). Diffusion of innovation (5th ed.). New-York: The Free Press. 
Spencer, C. (2006). Research on learners' preferences for reading from a printed text or from a computer screen. The Journal of Distance Education / Revue de l'Éducation à Distance [Online] 21(1), 33-50. Retrieved February 27, 2008 from http://www.jofde.ca/index.php/jde/article/view/70/51

Travica, B. (2007). Of disobedience, divinations, monsters and fumbling: Adopting a self-service system. Journal of Information, Information Technology, and Organizations, 2(1), 15-29. Retrieved from http://jiito.org/articles/JIITOv2p015-029Travica258.pdf

Venkatesh, V., \& Morris, M. G. (2000). Why don't men ever stop to ask for directions? Gender, social influence, and their role in technology acceptance and usage behavior. MIS Quarterly, 24(1), 115-139.

Venkatesh, V., Morris, G. M., Davis, G. B., \& Davis, F. D. (2003). User acceptance of information technology: Toward a unified view. MIS Quarterly, 27(3), 425-478. 


\section{Appendix A. Instrument Items}

\begin{tabular}{|c|c|c|c|}
\hline Construct & Code & Items & Loading \\
\hline \multirow{2}{*}{$\begin{array}{l}\text { Attitude } \\
\text { towards New } \\
\text { Technologies }\end{array}$} & ATNT1 & It is important for me to use advanced technologies. & 0.937 \\
\hline & ATNT2 & I am interested in innovative gadgets. & 0.855 \\
\hline \multirow{2}{*}{$\begin{array}{l}\text { Attitude } \\
\text { towards } \\
\text { Change }\end{array}$} & ATC1 & It is easy for me to get used to new procedures. & 0.905 \\
\hline & ATC2 & It is easy for me to cope with changes. & 0.916 \\
\hline \multirow[t]{3}{*}{$\begin{array}{l}\text { Behavioral } \\
\text { Intention }\end{array}$} & BI1 & $\begin{array}{l}\text { I intend to use the system in all the occasions when it will } \\
\text { be easy for me to type the assignment (e.g., no graphs). }\end{array}$ & 0.810 \\
\hline & BI2 & $\begin{array}{l}\text { I hope that in the future the assignments system will be } \\
\text { available in all the courses. }\end{array}$ & 0.863 \\
\hline & $\mathrm{BI} 3$ & I will use the assignments system. & 0.890 \\
\hline \multirow[t]{2}{*}{ Compatibility } & COM1 & I have used the system when I needed fast response. & 0.872 \\
\hline & COM2 & $\begin{array}{l}\text { I have used the system when it was easy for me to type the } \\
\text { assignment. }\end{array}$ & 0.716 \\
\hline \multirow[t]{2}{*}{ DisTrust } & DisTrust1 & $\begin{array}{l}\text { It scares me to think that I could lose an assignment by } \\
\text { hitting the wrong key. }\end{array}$ & 0.885 \\
\hline & DisTrust2 & $\begin{array}{l}\text { I hesitate to use the system for fear of making mistakes I } \\
\text { will not be able to correct. }\end{array}$ & 0.874 \\
\hline \multirow[t]{3}{*}{ Experience } & Exp1 & I have full command of sending and receiving e-mails. & 0.831 \\
\hline & Exp2 & I know how to scan simple documents. & 0.756 \\
\hline & Exp3 & $\begin{array}{l}\text { I am highly proficient in using Office software such as } \\
\text { MSWord and Excel. }\end{array}$ & 0.759 \\
\hline \multirow{2}{*}{$\begin{array}{l}\text { Institutional } \\
\text { Influence }\end{array}$} & II1 & In general, the University encourages use of the system. & 0.867 \\
\hline & II2 & $\begin{array}{l}\text { The tutors and course coordinators are strongly promoting } \\
\text { the use of the system. }\end{array}$ & 0.912 \\
\hline \multirow{3}{*}{$\begin{array}{l}\text { Perceived } \\
\text { Ease of Use }\end{array}$} & PEOU1 & The system is easy to use. & 0.811 \\
\hline & PEOU2Inv & $\begin{array}{l}\text { Personally, it is easier for me to send the assignment by } \\
\text { regular mail. }\end{array}$ & 0.767 \\
\hline & PEOU3Inv & In my opinion, the system is cumbersome and confusing. & 0.907 \\
\hline \multirow[t]{3}{*}{$\begin{array}{l}\text { Perceived } \\
\text { Usefulness }\end{array}$} & PU1 & $\begin{array}{l}\text { Using the system decreases the risk that an assignment } \\
\text { will be lost when handled by the postal service or by the } \\
\text { University academic and administrative staff. }\end{array}$ & 0.798 \\
\hline & PU2 & $\begin{array}{l}\text { It is more convenient to appeal or ask the course team for } \\
\text { clarifications if the assignment has been submitted through } \\
\text { the assignments system. }\end{array}$ & 0.763 \\
\hline & PU3 & $\begin{array}{l}\text { Using the system provides me with flexibility in the as- } \\
\text { signment submission time. }\end{array}$ & 0.753 \\
\hline \multirow[t]{3}{*}{ Real Value } & RV1 & $\begin{array}{l}\text { The assignments system helps me in my studies due to the } \\
\text { relatively fast feedback on my assignments. }\end{array}$ & 0.891 \\
\hline & RV2 & $\begin{array}{l}\text { The assignment system can help me study for the exam } \\
\text { because it keeps all the assignments along with the tutor's } \\
\text { feedback. }\end{array}$ & 0.786 \\
\hline & RV3 & $\begin{array}{l}\text { Using the system provides me with faster feedback on the } \\
\text { assignment compared to using the postal service. }\end{array}$ & 0.808 \\
\hline \multirow{4}{*}{$\begin{array}{l}\text { Social } \\
\text { Influence/ } \\
\text { Observability }\end{array}$} & SI1 & Fellow students recommended me to use the system. & 0.829 \\
\hline & SI2 & Other students that I know use the assignments systems. & 0.843 \\
\hline & OB1 & $\begin{array}{l}\text { I have already heard from some students that they use the } \\
\text { system and are satisfied with it. }\end{array}$ & 0.807 \\
\hline & OB2 & $\begin{array}{l}\text { I have heard from students who used the assignments sys- } \\
\text { tem that they received faster feedback. }\end{array}$ & 0.797 \\
\hline \multirow[t]{2}{*}{ Voluntariness } & VOL1 & There is a feeling of obligation to use the system. & 0.850 \\
\hline & VOL2 & $\begin{array}{l}\text { In courses where I have used the system, the course team } \\
\text { has created a feeling of obligation to use the system. }\end{array}$ & 0.835 \\
\hline
\end{tabular}


Appendix B. Confirmatory Factor Analysis in PLS

\begin{tabular}{|c|c|c|c|c|c|c|c|c|c|c|c|c|c|}
\hline & 章 & $\overrightarrow{3}$ & $\underline{\sigma}$ & $\stackrel{8}{3}$ & 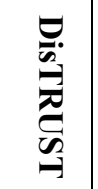 & 気 & $\begin{array}{l}\text { Qे } \\
\text { 产 }\end{array}$ & ニ & $\stackrel{\overrightarrow{0}}{0}$ & $\Xi$ & $\underset{\gamma}{\pi}$ & $\underset{\boldsymbol{\sigma}}{\mathscr{\sigma}}$ & $\grave{\varrho}$ \\
\hline & & 0.330 & & 0.281 & .061 & 223 & 0.063 & & 0.303 & 38 & 390 & 0.305 & \\
\hline & 55 & 230 & 323 & 0.303 & .061 & 229 & -0.107 & 0.109 & 176 & & 291 & 58 & 0.1 \\
\hline TC & 284 & 0.905 & 0.309 & 0.097 & -0.377 & 586 & -0.030 & 0.056 & 0.324 & & 49 & .052 & -0.0 \\
\hline TC & 01 & 0.916 & 0.339 & 0.082 & -0.251 & 0.462 & -0.124 & 0.038 & 0.249 & 230 & .195 & .131 & -0.0 \\
\hline I1 & & 222 & 810 & 0.501 & .175 & 0.133 & 0.034 & 0.1 & 0.426 & 461 & .548 & & 0.19 \\
\hline 12 & 79 & 0.398 & 863 & 0.280 & -0.298 & 0.240 & -0.033 & 0.063 & 0.560 & 512 & .446 & .314 & 0.090 \\
\hline 13 & 16 & 0.290 & 890 & 0.326 & -0.207 & 0.165 & 0.016 & 0.059 & 0.547 & 481 & .463 & 0.360 & 0.141 \\
\hline 1 & 44 & 0.007 & 285 & 0.872 & 0.071 & -0.005 & 0.060 & 0.255 & 0.160 & 280 & .513 & .424 & 0.432 \\
\hline $\boldsymbol{D}_{1}$ & 80 & 0.182 & 432 & 0.716 & -0.106 & 0.157 & -0.015 & 0.212 & 0.237 & 0.166 & 0.404 & 0.321 & 0.185 \\
\hline$S 1$ & 057 & -0.338 & -0.256 & -0.007 & 0.885 & -0.297 & 0.039 & -0.038 & 0.323 & -0.025 & -0.037 & 0.060 & 0.155 \\
\hline DIS 1 & .061 & -0.263 & -0.212 & 0.003 & 0.874 & -0.297 & -0.022 & -0.027 & -0.299 & -0.125 & -0.047 & -0.030 & 0.093 \\
\hline (p) & 147 & 0.362 & 0.223 & 0.083 & -0.339 & $\mathbf{0 . 8 3 1}$ & 0.029 & 0.036 & 0.214 & 0.064 & 0.144 & 0.041 & -0.025 \\
\hline p & 84 & 0.450 & 203 & 0.117 & .175 & 0.756 & -0.066 & -0.016 & 0.131 & 0.013 & 0.068 & -0.014 & -0.018 \\
\hline p & & 0.589 & 057 & -0.016 & -0.232 & 0.759 & 0.041 & -0.005 & 0.095 & -0.070 & -0.039 & -0.099 & -0.07 \\
\hline n & 006 & -0.086 & 006 & 0.036 & 0.010 & 0.013 & .000 & -0.021 & 0.125 & 0.082 & 0.151 & 0.198 & -0.036 \\
\hline & & 0.067 & 0 & 0.277 & -0.048 & 0.069 & 002 & 0.867 & 0.108 & & .257 & 287 & 0.144 \\
\hline & & 027 & & 0.250 & -0.021 & -0.034 & -0.036 & 0.912 & 0.083 & .030 & .166 & 01 & 0.244 \\
\hline & & 355 & & 0.223 & .274 & 0.190 & 0.102 & 0.232 & 0.811 & 372 & .357 & 329 & 0.044 \\
\hline & & 131 & & 0.194 & .268 & 0.097 & 120 & -0.041 & 0.767 & 290 & 0.284 & 239 & 0.027 \\
\hline 0 & & 284 & 0 & 0.177 & -0.336 & 0.201 & 092 & 0.064 & 0.907 & 0.404 & 0.340 & .251 & -0.041 \\
\hline $\mathrm{J}$ & & 215 & & 0.131 & .142 & 0.059 & 05 & 0.003 & 0.398 & 798 & .360 & 275 & 0.101 \\
\hline & & 201 & & 0.269 & -0.040 & 0.039 & 063 & 0.107 & 0.265 & 0.763 & .443 & 407 & 0.145 \\
\hline & & 046 & 469 & 0.268 & -0.015 & -0.063 & 120 & 0.056 & 0.330 & 0.753 & .411 & 350 & 0.136 \\
\hline & & 194 & & 0.491 & .045 & 0.080 & 132 & 0.211 & 0.380 & 532 & .891 & 512 & 0.207 \\
\hline & & 234 & & 0.397 & -0.031 & 0.146 & 164 & 0.187 & 0.341 & 380 & 0.786 & 355 & 0.220 \\
\hline $2 \mathrm{V3}$ & & 047 & & 0.552 & -0.042 & -0.001 & .084 & 0.179 & 0.259 & 0.377 & .808 & .537 & 0.208 \\
\hline II1 & & 085 & & 0.377 & 0.005 & 0.033 & 175 & 0.199 & 0.240 & 364 & .446 & 829 & 0.256 \\
\hline 12 & & & & 355 & -0.001 & 0.012 & 159 & 0.347 & 0.308 & 398 & 447 & 843 & 0.242 \\
\hline & & & & 0.274 & -0.069 & -0.023 & 237 & 0.246 & 0.337 & 345 & 352 & 807 & 0.153 \\
\hline & & & & 503 & 0.098 & -0.075 & 099 & .279 & 0.208 & 350 & 579 & .797 & .345 \\
\hline & & & & & & & & 03 & 021 & 80 & 256 & 296 & \\
\hline & 0.100 & -0.0 & .040 & & 0.08 & $-0.00 /$ & -0.040 & 12 & & 0.090 & .165 & .25 & \\
\hline
\end{tabular}




\section{Appendix C. Correlation Matrix, Descriptives and Average Variance Extracted of Principal Components}

Mean, Standard Deviation, and PLS reliability together with the correlation among the constructs and their square root of the AVE. Correlations of latent variables and Square Root of the AVE are presented in the diagonals.

\begin{tabular}{|c|c|c|c|c|c|c|c|c|c|c|c|c|c|c|c|c|}
\hline & $\begin{array}{l}\frac{3}{8} \\
\stackrel{3}{=}\end{array}$ & 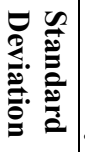 & 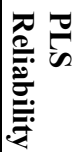 & 胥 & $\frac{B}{2}$ & $\underline{\underline{\sigma}}$ & $\stackrel{2}{3}$ & 몸. & 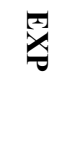 & $=$ & $\stackrel{\overrightarrow{0}}{0}$ & $\tilde{c}$ & $\underset{\psi}{\nabla}$ & $\stackrel{\omega}{\mathscr{\omega}}$ & $\stackrel{\varrho}{\varrho}$ & $\begin{array}{l}9 \\
\stackrel{9}{9} \\
\frac{9}{9}\end{array}$ \\
\hline ATNT & 4.99 & 1.54 & 0.89 & 0.805 & 0 & 0 & 0 & 0 & 0 & 0 & 0 & 0 & 0 & 0 & 0 & 0 \\
\hline ATC & 5.98 & 1.07 & 0.91 & 0.321 & 0.830 & 0 & 0 & 0 & 0 & 0 & 0 & 0 & 0 & 0 & 0 & 0 \\
\hline BI & 5.54 & 1.49 & 0.89 & 0.468 & 0.356 & 0.731 & 0 & 0 & 0 & 0 & 0 & 0 & 0 & 0 & 0 & 0 \\
\hline COM & 4.19 & 1.43 & 0.78 & 0.321 & 0.098 & 0.428 & 0.637 & 0 & 0 & 0 & 0 & 0 & 0 & 0 & 0 & 0 \\
\hline DisTRUST & 2.56 & 1.46 & 0.87 & -0.067 & -0.343 & -0.266 & -0.002 & 0.774 & 0 & 0 & 0 & 0 & 0 & 0 & 0 & 0 \\
\hline EXP & 6.30 & 0.91 & 0.83 & 0.249 & 0.573 & 0.211 & 0.076 & -0.338 & 0.613 & 0 & 0 & 0 & 0 & 0 & 0 & 0 \\
\hline II & 4.48 & 1.42 & 0.88 & 0.111 & 0.051 & 0.109 & 0.294 & -0.037 & 0.014 & 0.792 & 0 & 0 & 0 & 0 & 0 & 0 \\
\hline PEOU & 5.70 & 1.25 & 0.87 & 0.279 & 0.313 & 0.600 & 0.237 & -0.354 & 0.199 & 0.106 & 0.690 & 0 & 0 & 0 & 0 & 0 \\
\hline PU & 5.36 & 1.24 & 0.82 & 0.319 & 0.197 & 0.567 & 0.288 & -0.085 & 0.014 & 0.070 & 0.431 & 0.595 & 0 & 0 & 0 & 0 \\
\hline RV & 4.68 & 1.38 & 0.87 & 0.387 & 0.190 & 0.566 & 0.580 & -0.048 & 0.088 & 0.232 & 0.395 & 0.524 & 0.688 & 0 & 0 & 0 \\
\hline $\mathrm{SI} / \mathrm{OB}$ & 4.46 & 1.38 & 0.89 & 0.307 & 0.101 & 0.430 & \begin{tabular}{|l|l}
0.472 \\
\end{tabular} & 0.018 & -0.020 & 0.330 & 0.329 & 0.445 & 0.569 & 0.671 & 0 & 0 \\
\hline VOL & 3.63 & 1.49 & 0.83 & 0.202 & -0.028 & 0.163 & 0.408 & 0.142 & -0.049 & 0.223 & 0.009 & 0.165 & 0.253 & 0.314 & 0.711 & 0 \\
\hline Gender & 0.55 & 0.50 & & -0.006 & -0.086 & 0.006 & 0.036 & 0.010 & 0.013 & -0.021 & 0.125 & 0.082 & 0.151 & 0.198 & -0.036 & 1 \\
\hline
\end{tabular}




\section{Biography}

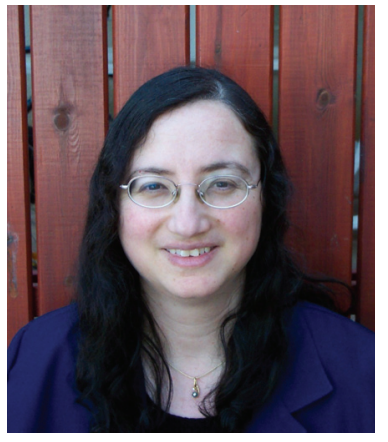

Nitza Geri is Head of Undergraduate Management Studies at the Department of Management and Economics at The Open University of Israel and a member of the Chais Research Center for the Integration of Technology in Education. She holds a B.A. in Accounting and Economics, an M.Sc. in Management Sciences and a Ph.D. in Technology and Information Systems Management from Tel-Aviv University. Nitza is a CPA (Israel) and prior to her academic career she had over 12 years of business experience. Her research interests and publications focus on various aspects of the value of information, and information systems adoption and implementation, which include strategic information systems, e-business, value creation and the Theory of Constraints, managerial aspects of e-learning systems adoption and use.

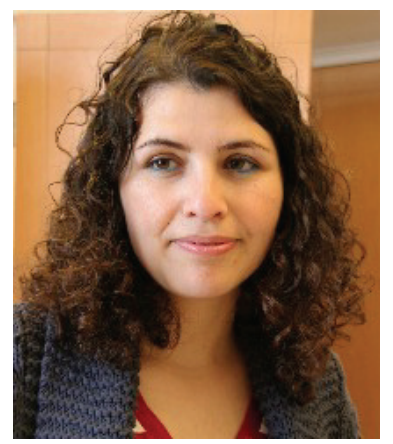

Orit Naor-Elaiza is a Graduate student at the Graduate School of Business Administration, Bar-Ilan University. She holds a B.A. in Management and Computer Science from the Open University of Israel. Orit is Head of the sub-department of data analysis and processing at the Human Resources Administration of The Open University of Israel, and she has over eight years of professional experience. Her area of research is technology acceptance. 